\title{
Urodimento
}

REVISTA DE ESTUDOS EM ARTES CÊNICAS

E-ISSN 2358.6958

\section{Cabaré nas engrenagens da máquina cidade}

\author{
Ricardo Bertola Nolasco da Silva \\ Amabilis de Jesus da Silva \\ Gabriel Matheus Lopes Machado
}

Para citar este artigo:

SILVA, Ricardo Bertola Nolasco da; SILVA, Amabilis de Jesus da; MACHADO, Gabriel Matheus Lopes. Cabaré nas engrenagens da máquina cidade. Urdimento - Revista de Estudos em Artes Cênicas, Florianópolis, v. 2, n. 41, set. 2021.

doi) DOI: http:/dx.doi.org/10.5965/1414573102412021e0108

Este artigo passou pelo Plagiarism Detection Software| iThenticate 


\title{
Cabaré nas engrenagens da máquina cidade
}

\author{
Ricardo Bertola Nolasco da Silva ${ }^{1}$ \\ Amabilis de Jesus da Silva ${ }^{2}$ \\ Gabriel Matheus Lopes Machado ${ }^{3}$
}

\begin{abstract}
Resumo
Este artigo trata do entrecruzamento de temporalidades e remapeamento do processo de ocupação urbana desenvolvido durante a criação de Cabaret Macchina - uma pós-ópera anti-edipiana da Casa Selvática. A imagem da erva daninha, esse tipo de vegetação preterida que surge entre as fendas da cidade, aparece como desdobramento poético-visual, o cabaré - linguagem do submundo, do que está abaixo da terra (underground) e na noite - emerge em praça pública, no dia a dia, a luz do sol. Para dar vazão às ramificações desta estranha vegetação, mescla-se relatos de três criadoras, mas que aqui foram reunidas como uma única conferencista, com o intuito de mover as peças, e borrar onde começaria e onde terminaria cada engrenagem dessa máquina-cabaré.
\end{abstract}

Palavras-chave: Cabaré. Coletivo. Precariedade. Processual. Espaço público.

\section{Cabaret on the gears of the Machine City}

\begin{abstract}
This paper presents the intersection of temporalities and the remapping of the process of urban occupation developed during the making of Cabaret Macchina uma pós-ópera anti-edipiana Casa Selvática. The imagery of the weed, those small unwanted plants that grow between concrete blocks along the city, unfold as a poetic-visual, The cabaret emerges from the underground to everyday life, taking place at public spaces in broad day light. To flow rate branches at such odd vegetation, blended it here the narration from three creators, but united as an only one lecturer in order to move the pieces, and blurring the margins between gears from this cabaret machine.
\end{abstract}

Keywords: Cabaret. Collective. Processual Art. Precariousness. Public spaces.

\footnotetext{
${ }^{1}$ Mestrando em Artes Cênicas pela Universidade Federal do Estado do Rio de Janeiro (UNIRIO). Bacharelado em Artes Cênicas pela Universidade Estadual do Paraná (UNESPAR). Integrante-fundador da Selvática Ações Artísticas (2011). Artista de cabaré. ricardonolasco@edu.unirio.br

(9) http://lattes.cnpq.br/0769132810755743 (i) https://orcid.org/0000-0003-3826-5920
}

2 Doutora em Artes Cênicas pela Universidade Federal da Bahia (2010). Professora do Programa de PósGraduação em Artes e do curso de Bacharelado em Artes Cênicas da Universidade Estadual do Paraná (UNESPAR - Campus de Curitiba II - FAP). Figurinista. amabilis.jesus@gmail.com

\section{(9) http://lattes.cnpq.br/7668645752206910 iD https://orcid.org/0000-0001-6708-5297}

${ }^{3}$ Mestrando em Artes da Cena pela Universidade Federal do Rio de Janeiro (UFRJ). Bacharelado em Artes Cênicas pela Universidade Estadual do Paraná (UNESPAR) Integrante-fundador da Selvática Ações Artísticas (2011). Artista e pesquisador da dança. gabrielmlmachado@gmail.com

(6) http://lattes.cnpq.br/2727242611193274 (iD https://orcid.org/0000-0002-4028-8497 


\section{Resumen}

Este artículo trata sobre el entrelazamiento de temporalidades y el replanteamiento del proceso de ocupación urbana desarrollado durante la creación de Cabaret Macchina - uma pós-ópera anti-edipiana Casa Selvática. La imagen de la mala hierba, ese tipo de vegetación desaprovechada que aparece entre las grietas de la ciudad, aparece como un despliegue poético-visual. Emerge el cabaret - lenguaje del inframundo, de lo que hay bajo tierra (underground) y en la noche - en plaza pública, en el dia a dia, a la luz del sol. Para mirar a las ramificaciones de esta rara vegetación, se mezclan relatos de tres creadoras, pero que se reunieron aquí como una sola presentadora, con el objetivo de mover las piezas, y difuminar dónde comenzaría y terminaría cada engranaje de esta máquina-cabaret.

Palabras clave: Cabaret. Colectivo. Precariedad. Procesal. Lugar público. 


\section{Brotamento}

Respeitável público, leitora e leitor, utilizamos um espetáculo criado coletivamente nas e para as ruas a fim de refletir como pode o cabaré ser uma máquina erva daninha e se locomover fincando suas raízes que não são centrais, mas discordes, polifônicas e simbióticas. Como uma planta trepadeira o cabaré se apropria de todo material precário que está em seu caminho para edificar espetáculo e resistência: possibilidade efêmera para se manter vivo.

Jean Bourriaud (2009, p.57) propõe com radicante uma estética da mobilidade e das negociações, já que essas plantas deslocam a sua territorialidade enquanto se adaptam aos terrenos realizando intercâmbios culturais. Isto parece se relacionar diretamente com um espetáculo de cabaré que tem na mobilidade e na relação com o território - sempre provisório - sua principal fonte de criação e consequentemente de burla.

A coreografia do cotidiano e dos carros, em meio à sinfonia de buzinas e sirenes, às canções dos vendedores de ouro ou loteria, entre fiações e encanamentos, em espaços abandonados nas grandes cidades. Será que é possivel propor outras realidades para-espetaculares e provisórias que ressaltem que o mundo é um cabaré?

Olhe por essa fresta-cidade aberta e todas as suas desigualdades como possibilidade para fazer dela cabaré, imaginando um novo mundo possível. Dela nasce nosso cabaré erva daninha, expondo processo de vida e arte de uma máquina desejante capaz de sempre se reagrupar e recombinar. A cidade é uma máquina organismo vivo e pode abrigar outras vidas.

Ao observar a vida de determinadas bactérias, a bióloga Lynn Margulis aponta como as vidas de todos os seres vivos terrestres dependem de ações coletivas, que envolvem inumeráveis microcosmos. Simbioses constantes que em milhões de anos de promiscuidades entre pequenos seres, micróbios e outros organismos configuraram isto que chamamos de planeta e de vida, inclusive a vida humana. "Todos os 30 milhões de espécies de nós, têm origem no microcosmo" (Margulis, 2001, p.17). A vida não existe sozinha, sem convivência, "o contato físico é um 
requisito inegociável para muitos tipos diferentes de vida" (Margulis, 2001, p.12). Nesse movimento entre os pequenos mundos em suas diferentes formas de vida nos interessa observar as partes que desarranjadas e fragmentadas constroem uma possível máquina. Como algumas bactérias que para respirar formam pequenas bolhas nas folhas de determinadas plantas, o cabaré aqui apresentado sai do submundo em busca de respirar a cidade, estabelecer contato com o ambiente e modificar-se.

O cabaré é uma planta parasita que se alojou na estrutura dessa máquina cidade e foi se proliferando, alastrando e quando se percebeu eram muitas e já tinham seus próprios fluxos, mecanismos e roldanas. Cresceu em meio à caliça que já não pode ser removida, é um fungo, umidade penetrante que não se sabe muito bem de onde brota. Não sustenta apenas uma oposição às grandes estruturas fascista fascinantes (Sontag, 1986) que regem a criação artística, mas é a própria construção ou exercício de uma possibilidade artística que permita outras perspectivas para a espetacularidade que estamos inseridas.

Guy Debord (1973) alertou que parte da eficiência do espetáculo consiste em não esconder completamente que alguns perigos cercam a ordem do maravilhamento. Os grandes espetáculos sempre ocultam um histórico de dominação. Não nos enganemos, "quem quer que tenha emergido vitorioso participa do cortejo universal no qual dominadores do presente pisam sobre os que jazem prostrados" (Benjamin, 1987, p.70). Tanto como oposição a um fascínio cego que rege a arte mercadológica e seguindo o legado de Benjamin (Benjamin, 1987, p.70) de "escovar a história a contrapelo/ler a história ao revés", a espetaculariedade e a presença cabareteira na cidade revelam que tudo é espetáculo e deste modo propõem novas organizações, máquinas, ramificações, utopias e outras performatividades menos totalitárias.

O cabaré como gênero possui um interesse intrínseco em tudo que é inacabado, afinal é apenas no que não foi finalizado que existe a possibilidade de ser continuado ou desdobrado. Christina Streva (2017, p.156) comenta que "tratase de uma linguagem do desvio, do atravessamento, da mistura e dos extremos e, portanto, qualquer tentativa de se amarrar ou de se categorizar demais o cabaré é contrário à sua própria natureza”. 
Dessa forma quando se opõe tão abertamente aos grandes espetáculos se relaciona com a visão do trabalho em processo como uma proposição utópica, sendo assim como o work in progress "inteiramente dependente do processo, sendo permeado pelo risco, pelas alternâncias dos criadores e atuantes e, sobretudo, pelas vicissitudes do percurso" (Cohen, 2004, p.18). A processualidade é inerente ao cabaré, que a abriga desde o seu surgimento.

Obra viva e em movimento como máquina orgânica-sintética em constante relação com o ambiente em que se insere, na medida que se move se modifica e também modifica assim o seu entorno. Como aponta Lívia Sudare (2019, p.52), “o cabaré, por ser um gênero em processo, esteve, desde o seu surgimento, aberto a fusões". Misturas que muitas vezes vão aderindo a esse corpo cabareteiro erva daninha na medida em que é realizado. Essas misturas são o maior atrativo do cabaré, derivado dos espetáculos de variedades sempre foi uma forma de oportunizar sentimentos e sensações variadas em uma mesma noite, além de se colocar visivelmente distante dos gêneros considerados puros pela tradição das artes cênicas, preferindo parodiar os formatos oficiais.

Ao falar do encontro do cabaré com o teatro de revista na Alemanha durante a República de Weimar, Sudare destaca um novo formato: a Revuette, que iremos comentar mais a frente por se relacionar com a máquina cabaré tanto por parecerem presentes nas proposições de Heiner Müller, assim como nas de seu predecessor Bertolt Brecht, admiradores e muito influenciados pelo cabaré produzido na Alemanha como resistência ao nazismo, mas também por se relacionar com o estudo específico de cabaré realizado por esse coletivo e suas vedetes cabaretas.

Enquanto gênero o cabaré já possui em sua indisciplinariedade (não pertencendo a essa ou aquela linguagem artística, mas transportando fronteiras) esse caráter radicante. No caso da proposição do cabaré como máquina e erva daninha, o deslocamento apresenta-se como principal característica da sua composição, propondo experiências outras na relação com a cidade através do cabaré, que por sempre estar em deslocamento possibilita uma renovação do olhar tanto do público que já vai com a intenção de ver o espetáculo, como do passante que acidentalmente se vê inserido em um cabaré político em meio ao 
seu caminho rotineiro.

Este texto, pretende através de um procedimento autoetnográfico (Fortin, 2006) propor reflexões em um formato híbrido entre o relato de processo e discussões teóricas que perpassam as questões relevantes ao cabaré contemporâneo. Acreditamos que essa seja uma contribuição importante para o estudo do cabaré: compartilhar um pouco do processo de um coletivo de 17 artistas pesquisadores e seus corpos dissidentes em tensionamento com o espaço público e suas lógicas pré-estabelecidas, utilizando a obra de Heiner Müller como disparadora de uma experiência cênica envolvendo teatro, dança, performance e música. A proposição é que a leitora/leitor nos acompanhe por esse texto deriva na aventura de realizar uma máquina cabaré que deseja ser erva daninha no espaço público, uma forma de refletir sobre o exercício cabareteiro.

Também é um convite para acompanhar esse cabaré que agora se faz em texto, assim como na estrutura do espetáculo nossas apresentadoras/mestres de cerimônia assumem diferentes vozes e corporalidades, são diferentes caligrafias, fragmentos e escritas que se juntam com o objetivo de compreender a experiência de transportar um gênero como o cabaré, que acontece muitas vezes em lugares secretos ou escondidos, para a cidade, e posteriormente para este texto, não menos cabareteiro, não menos fragmentado, não menos inacabado e não menos precário.

Por esse motivo se entrecruzam o que chamamos de fendas: desdobramentos que buscam apresentar pontos de vista distintos da equipe desse cabaré, poucas das muitas ramificações possíveis dessas abordagens se entrelaçam como plantas que vão se enraizando em torno da cidade em um desdobramento vegetal maquínico.

Sejam todas bem vindas a essa máquina erva daninha: cabaré!

\section{Fenda 1: A Máquina}

Senhoras e senhores apresentamos nessa noite uma cidade no sul. Percebam, ao olhar pro horizonte, que tudo é espetáculo. Luar, nuvens, prédios, ruas planejadas por uma equipe eficiente de cenografia. É tudo encenação! Atrás desses prédios não existe nada mais do que linhas que 
se cruzam nesse espetáculo que é apenas o que podemos oferecer. A cidade é uma ferida aberta. O nosso drama é o marco central de todas as periferias do mundo. Artistas de Cabaré fogem de seus bueiros, tocas e frestas na busca por um herói. Ou melhor...Uma heroína. Poderíamos chamar isso de máquina! Máquina desejante produzindo vida. Não iremos cantar nada que não seja uma tentativa de artistas em uma praça pública. Não nos esconderemos. Somos e seremos máquina cidade. ${ }^{4}$

Uma máquina cabaré feita de carne e contradição é montada e desmontada em movimento contínuo em uma praça ou fresta possível. É um corpo precário que se abre. Exército de artistas buscando ser engrenagem falha fracasso em meio a eficiência idealizada e espetacular de uma grande cidade. Se movem em bando, respiram o discreto charme do precariado (Akseli, 2011), têm medo, gargalham, assustam crianças e passantes. Máquina utopia de proporções gigantescas, pequena mancha em meio à cidade que nunca para.

Pontos de ônibus, vendedores, um grupo de orações, uma briga com faca, formas diversas de sobrevivência na cidade e esses artistas também aqui. Uma cidade são muitas cidades e essa máquina é um cavalo de Tróia: mistura de presente e veneno que não se sabe muito bem de onde veio.

A máquina é espalhafatosa, barulhenta, intrusiva e polifônica. Parece nunca conseguir concordar consigo mesma. Briga, grita e grunhe. A máquina pensa conseguir ficar invisível em meio a polis, mas sempre deixa suas penas e purpurinas por onde passa. Essa máquina não podia ser diferente do que é por ser cabaré, dissidência e espetáculo revelado.

Suas engrenagens não parecem vir do mesmo lugar, falam línguas dessemelhantes, tem corporalidades muito distintas entre si. Talvez seja essa diferença que produza semelhança capaz de unir as partes e fazer delas a mesma máquina. Algumas vezes não se consegue decifrar nada do que dizem, outras parecem incitar revolta ou revolução. É difícil entender o que fazem nessa praça na capital mais fria do país.

Simetria disforme - tudo está um tanto non sense e fora de ordem: corpos estranhos, desengonçados e paródicos tentam marchar como policiais, discursar

\footnotetext{
${ }^{4}$ Trecho retirado do texto do espetáculo.
} 
como políticos, convencer como militantes, fazer propaganda. Pedem que os acompanhem, mas não dizem para onde estão nos levando. Máquina patafísica. A lógica está desregulada. Por um lado quer identificação, por outro não parece ter interesse em agregar. Máquina de dissidências, máquina de desagregar. Não é família, nem nação, nem grupo. Como responder o que é essa máquina cabaré polifonia?

Estas artistas não estavam na cidade para consertá-la, resolvê-la, traduzi-la ou qualquer outro sentido de intervenção. Mas, pelo contrário, a criação de estratégias para estar e relacionar-se com as múltiplas linhas de seu caos e incorporá-lo como matéria de criação (Sejanes, 2020, p. 57).

O cabaré não é o espaço da totalidade e do univocal que vemos nos grandes espetáculos e seus princípios de fechamento e conclusão, o cabaré tem a polifonia como um princípio utópico: além da multivocalidade inevitável, essa é radicalizada como maneira dos discursos jamais se finalizarem, são sempre abertos: "vozes e consciências que circulam e interagem num diálogo infinito" (Faraco, 2003, p. 74).

Enquanto a univocalidade e a universalidade buscam sempre o fechamento, a palavra final, essa máquina é a simples presença de artistas de cabaré e seus corpos dissidentes no espaço público no ano de 2018. Como se fora em 0 Rinoceronte de Ionesco o fascismo dava as caras nas ruas, mais uma vez de verde e amarelo, artistas eram presos e perseguidos em diferentes contextos no Brasil, a vereadora Marielle Franco assassinada no Rio de Janeiro alguns dias antes da estreia deste cabaré. "Eles são artistas, são perigosos"5 - a máquina grita em meio a praça Rui Barbosa, como quem se entrega e tenta evidenciar um pouco as coisas em um ato de sinceridade.

Essa máquina é de desejo e guerra.

Paródica.

Violenta.

Cuidado, in progress!

5 Trecho retirado do texto do espetáculo. 


\section{Fenda 2: Mecânicas, malogros e vendavais}

"Sou um homem ou uma máquina?" perguntou Baudrillard (2004), ao que ORLAN parece responder com sua obra "esse é meu corpo, este é meu software" (1986), em consonância radical com Donna Haraway, que por sua vez traz questões relevantes para olharmos uma máquina de cabaretistas dentro de uma máquina cidade: "tanto construir quanto destruir máquinas, identidades, categorias, relações, narrativas espaciais. Embora estejam envolvidas, ambas, numa dança em espiral, prefiro ser uma ciborgue a uma deusa" (Haraway, 2009, p.99).

Máquina radicante que traz a multivocalidade em cada palavra, som ou movimento. Se assume como máquina desejante anti-edipiana em uma cidade arquitetura de opressões que jamais pode esconder sua missão de coibir desejo e respirar Édipo junto a todos os seus complexos. A máquina cabaré destoa de tudo ao seu redor, não parece ter qualquer função, e por isso mesmo não poderia estar em outro lugar. É uma máquina quando é perceptível que todas as utopias mecânicas falharam.

Também não carrega em si nenhuma tecnologia de ponta, mas é sim máquina precária composta pelo rudimentar corpo humano e talvez a sua mais antiga ação: o encontro. Até pode ser adornada com microfones, palavras de ordem, discursos elaborados, penas e luzes de led. Mas é singela e verdadeira como geralmente é o cabaré: precário, contraditório e efêmero. Reconta histórias que talvez já sejam nossas velhas conhecidas, um pouco mais do mesmo Hamlet, Medea ou Édipo. Relidos, traduzidos, recriados para ruas e praças de Curitiba por uma mecânica de transubstanciar e recontextualizar.

A máquina cabaré se relacionava com Heiner Müller em um momento em que discursos fascistas ganhavam popularidade no Brasil. Um contexto que se relaciona em alguma medida com o da produção mülleriana. Não é difícil se reportar à Karl Marx (2011, p.25) quando aponta que a história se repete "a primeira vez como tragédia, a segunda como farsa". É em meio a essa farsa, embora não por isso menos trágica, que reside a importância dessa máquina ir para a rua: talvez somente para escancarar o espetáculo já instaurado. 
Heiner Müller disse que: "Não teremos chegado a nós enquanto Shakespeare escrever as nossas peças" (apud Marcondes, 2014, s/p), e essa máquina coletiva sabia que também não seríamos nós enquanto Müller escrever nossos pósdramas. Assim, as frases de Müller invadiam a praça "eu quero ser uma máquina”, mas uma própria engenhoca precária e tupiniquim, ou "máquina de fuder" como diz a canção das Horrorosas Desprezíveis cantada pelas vedetes nesse cabaré. Não é mais o mesmo Hamlet. Nem o de Shakespeare, nem o de Müller. É um Hamlet que diz "Ser ou não ser, sem um tostão"6.

Hamlet. Anti-Hamlet. Pré-Hamlet. Pós-Hamlet. Hamlet-Máquina. HamletTrash?7. Telmah. Medea. Des-medeå ${ }^{8}$ Medea Material. Medea Metal. Deus Ex Macchina. Édipo. Anti-édipo. Medea - vagina dentada, mulher monstro. Lady Macbeth - mãos de sangue que nem todos perfumes da Árabia poderiam lavar. Mitos heroicos e arquetípicos da cultura ocidental e por consequência da modernidade, evidentes no pensamento psicanalítico, por exemplo, figuram lado a lado para serem relidos pelo humor corrosivo desse cabaré.

O tema da libertação das minorias alienadas veio substituir a retórica persuasiva do modernismo, mas transformando cada enunciado em objeto de uma suspeita maior: o universal moderno não teria sido mais do que a máscara sob a qual camufla a voz do 'macho branco' dominante (Bourriaud, 2009, p.13).

A posição levantada pelo pós-estruturalismo, em especial nos estudos multiculturais, em relação à quantidade de discursos, vozes, visões e pareceres calados por um princípio universalista das correntes modernas, denunciam a impossibilidade da formação de uma única voz. Mutilou-se um a um cada grande princípio moderno para dar espaço a discursos até então ignorados. Por outro lado, como aponta Terry Eagleton (1998), o multiculturalismo se fez refém de um sistema que dá voz a todos os discursos, mas desacredita das reais transformações das estruturas sociais ou artísticas. Assim, essa máquina cabaretera é erigida sobre esse paradoxo: se por um lado o modernismo quis falar

\footnotetext{
${ }^{6}$ Trecho retirado do texto do espetáculo.
}

7 Título da livre adaptação feita pelo diretor e autor Cesar Almeida.

${ }^{8}$ Dramaturgia de Denise Stoklos. 
em nome de muitos, a pós-modernidade deu voz a todos, mas arriscando substituir os "grandes ideais" apenas pelo exercício exaustivo da individualidade. Por isso é importante olhar ainda para o moderno (e o sonho maquínico) a fim de refletir acerca dos caminhos percorridos pelo curso da história, buscando não recair em duas armadilhas: o saudosismo por uma construção de pensamento que não encontra aplicabilidade no contemporâneo e a condescendência com o conformismo dos discursos pós-modernos. "Esse vendaval é o que chamam de progresso" (Benjamin, 1987, p.72).

\section{Fenda 3: Marchagrafia}

Praça pública, uma a uma, surgem passando pelo meio da audiência as vedetes que protagonizam esse cabaré. Engrenagens de uma máquina, partes da mesma planta. Se posicionam lado a lado frente a multidão. Começam a marchar ao som de uma oração em sânscrito. Não conseguem avançar porque o público está ali em número maior, se veem obrigadas a mudar a sua marchagrafia. A erva precisa encontrar outro sentido para poder crescer. Uma vedete quase cai de sua bicicleta.

Em uma segunda tentativa o público precisa ser empurrado por uma fita zebrada deixando o terreno livre para o seu desenvolvimento, já incorporando nesse ato as discussões sobre espetáculo e opressão que irão povoar todas as cenas do cabaré. Agora sim, as vedetes marcham em linha reta delineando um risco em toda a praça. Marcha paródica de alguma celebração cívica. Corpos estranhos em marcha depois de empurrar o público e conquistar seu espaço.

Em sua defesa por uma dancifiação da política a artista e pesquisadora Luca Naser Rocha propõe uma inversão analítica para olhar os movimentos que tomaram as ruas brasileiras de 2013 até o golpe que destitui a presidenta Dilma Rousseff em 2016: "si hemos hecho tanto análisis político de la coreografía quizás es hora de hacer un análisis coreográfico de la manifestación política" (Naser, 2017, $\mathrm{s} / \mathrm{p})$. Ao analisar imagens difundidas pela mídia, a pesquisadora se pergunta: qual seria a proposta coreográfica dos movimentos sociais e as estratégias políticas desses corpos que ocupavam as ruas? Quais são as possíveis diferenças (do ponto 
de vista do modo como os corpos ocupam as ruas) entre um movimento que surge organicamente contra o aumento da tarifa do transporte público, sua repressão e posteriormente um movimento vestido predominantemente de verde-amarelo com coreografias-marchas ensaiadas?

Utilizando uma ideia de coreografia que se aproxima dos conceitos de coreopolítica e coreopolícia desenvolvidos por André Lepecki (2013), Naser aponta diferentes coreografias criadas pelos corpos/multidões no espaço público, e aqui nos interessa três movimentos paradoxalmente em justaposição: 1) a coreografia da multidão que sai às ruas, em levante por melhores condições de cidadania; 2) a marchagrafia militarizada que visa reprimir a ação desses corpos no espaço; 3) a cooptação do movimento número um por grupos de direita e consequentemente sua transformação em coreografia com figurino verde-amarelo. Em justaposição temporal e espacial, três movimentos simultâneos em um jogo de guerra que nas filmagens aéreas as quais temos acesso, poderia se supor que tudo é encenação, tudo é coreografia.

Em 2018, pós-golpe, pré-eleição presidencial que elegeria Jair Bolsonaro, com as dicotomias e linhas de forças cada mais vez mais acirradas e uma guerra midiática instaurada, onde artistas e intelectuais foram postos na fogueira da inquisição moral e religiosa através de fakenews e distorções/deslocamento de suas obras dos contextos nos quais foram concebidas; um grupo de aproximadamente 17 artistas de cabaré decide ir para rua, fazer da cidade um cabaré, em alto e bom tom gritar: nós não nos esconderemos.

Corpos desejantes e ao mesmo tempo indesejados à luz do sol emergem ora despercebidos, ora em marcha, ora em pequena multidão. O cabaré, que tem no humor umas de suas principais ferramentas, se apropria dos movimentos 1, 2 e 3 citados acima, e em retomada do espaço, em deboche e corpos em luta, as vedetes se põem a marchar. Como seria um exército de artistas de cabaré? Será que é possível construir uma máquina que não seja opressiva? Pelo que e por que marcham tais vedetes na rua? Quais bandeiras são hasteadas neste cabaré? Quais coreopolíticas e coreopolícias estão neste jogo?

Se Paul B. Preciado (2011, p.14) nos falaria da Multidão Queer, enquanto 
processo de "desterritorialização da heterossexualidade", em Cabaret Macchina a Multidão Queer ressalta a diferença com ares cabareteiros e espetacularizados. Um jogo coreográfico entre público, artistas e passantes. Não há palco, as vedetes transformam as pequenas elevações e degraus da praça em escadarias, se estivéssemos em uma montagem clássica nos tempos áureos do Teatro de Revistas, tais escadas serviriam para exibir corpos esculturais e figurinos glamourosos. Porém, neste cabaré de rua em cenário de guerra, as vedetes se perdem em meio a multidão-máquina-público, a coreografia muito bem ensaiada cede lugar para outra onde todo e qualquer corpo pode dançar, exibir-se, seduzir, expor a urgência destes corpos-bandeiras freak hasteada ao infinito. A marcha coreografia mal executada e debochada, o passo descompasso, a precisão patética, a contagem confusão.

Bem como evidencia Marcelo de Troi (2018, p.118): "A Selvática, a partir de seus integrantes, reivindica esse local da via pública para ser palco de sua arte transgressora com corpos dissidentes não submissos e suas práticas performativas urbanas". E deste modo, a marchagrafia desenvolve sua mescla maquínica orgânica propondo a lógica de um exército estranho neste território. Reterritorializa a praça, deslocam a máquina e o público por uma aventura geográfica por ilhas em meio a multidão. Ocupam qualquer espaço: poste, canteiro, elevação. O terreno modifica radicalmente a marchagrafia que se faz dança, manifestação, ringue e desfile. É a marchagrafia o fio condutor que convida o público para se deslocar, tentar ver a próxima cena, insistir, ser radicante e fazer parte dessa engrenagem.

Tropeçar e falhar com essa máquina efêmera vegetal.

\section{Fenda 4: Erva Daninha}

O cabaré se instala em qualquer ponto da cidade.

Erva daninha que nasce em cada fresta.

A pós-ópera é zona autônoma temporária.

Permanecerá até ser enxotada.

Falamos do coração da cidade.

E tocamos o discreto charme do precariado. 
O barulho que se ouve é máquina de música, sons e rumori. oferecemos ondas sonoras para o próximo milênio. ${ }^{9}$

A máquina é erva daninha que se instala em qualquer fresta para fazer o seu cabaré. Reconta histórias usando humor, transgressão e a ocupação de espaços não convencionais. Metal em uma pele sensível. Jogo Ferida Obra Aberta10. Histórias de reis e rainhas em uma terra sem reis.

Ultra-espetacularidade subversiva, precária e debochada expõe, revela, burla e combate o grande espetáculo em que estamos inseridos. O cabaré assim não deseja ser grande obra de arte total, mas sim pós-opera anti-edipiana. Na mistura cabareteira despudorada de gêneros, formatos e discursos se expõe a falha e a possibilidade de malogro. Esta posição política, ética e estética se comunica com o que Mary Russo diz em sua análise sobre o grotesco e o corpo feminino:

O risco não é um mal a ser evitado, mas sim uma condição de possibilidade produzida, com efeito, pela normalização do corpo através de disciplinas na era moderna. O risco pertence ao discurso de probabilidade e "erro" [....] em geral o erro gera ideias e história (Russo, 2000, p.23).

Nesse sentido o cabaré tem que assumir as consequências e riscos de suas escolhas ao se opor com veemência a uma visão normativa da arte afastada da vida e de todos os atravessamentos que possam interferir nesse agora. Cabaré é evento irrepetível, acontecimento, uma espécie de zona autônoma temporária, a de Hakim Bey (2018). Imagine então o que acontece quando essa estética da fragmentação, hiper-espetacularidade e presença se encontra com um organismo também vivo e pulsante, embora repleto de regras e controle, como é o espaço público?

Talvez o espectador não consiga assistir tudo o que fazem as artistas e se perca em meio às cenas dispersas ou a uma massa que se desloca, como

9 Trecho retirado do programa do espetáculo.

10 Jogo Ferida Obra Aberta é como Ricardo Nolasco tem investigado a prática cabareta. Ressaltando o caráter aberto e processual do cabaré em diálogo com a proposta de obra aberta enunciada por Umberto Eco. Essa proposição busca olhar para o cabaré como um jogo em que existem roteiros e regras, mas também o espaço para a reorganização e a interferência do acaso, assim como a relação com as feridas que nunca são ocultadas no cabaré, mas sempre reveladas. 
aconteceu na estreia do espetáculo, em que uma multidão inesperada na audiência chegou a interferir diretamente no programa cabareteiro. Se no cabaré a cena não é apenas o que se passa no palco, na rua o cabaré se expande e dilata em uma inumerável proporção revelando que absolutamente tudo é espetáculo. É este o grande teatro do mundo, ninguém apagará a luz da plateia para que se veja melhor o sofrimento de um ator com um microfone pífio do que a senhora que perdeu o ônibus. O risco e o erro são iminentes e potenciais dessa proposta que precisará ser reconfigurada a cada nova apresentação.

O trabalho em processo não acontece somente no espaço-tempo anterior à apresentação, mas durante todo o curso do espetáculo e suas sucessivas apresentações, sendo conceitual, à semelhança dos processos vitais, essa constante mutação" (Cohen, 2004, p.30).

Essa vegetação maquínica radicante e espetacular que vai se deslocando por frestas e se entrelaça com os mecanismos urbanos modificando espaço e estruturas pode se relacionar com outro gênero derivado do cabaré, a Revuette, uma mistura do cabaré com o teatro de revistas. Criada pelo cabaretista alemão Friedrich Hollaender propunha "fornecer à revista ares literários e convicções políticas mais claras" (Sudare, 2019, p.52), além de demonstrar interesse em uma estrutura de amarrações dramatúrgicas diferente do sistema de quadros fragmentados tradicionalmente presentes nos cabarés. A revista sendo um formato popular, sensual e de entretenimento também sempre interessou ao coletivo que em Cabaret Macchina constrói uma espécie de Revuette para o espaço público a partir da obra de Heiner Müller reescritas pelas dramaturgas Francisco Mallmann, Leonarda Glück e Ricardo Nolasco.

As cenas desse cabaré reuniam personagens icônicas do teatro ocidental em um encontro de tessituras dramáticas deslocando do contexto mülleriano para o do coletivo. A escolha por uma estrutura conectiva entre os fragmentos que compõem a obra, presente no que chamamos de marchagrafia, era fundamental em um cabaré realizado no espaço público e que convidava ao deslocamento. Assim, como no Teatro de Revistas os números eram compostos por cenas variadas indo do manifesto à dança, passando pelas referências musicais ao humor. A estrutura pensava ligações e costuras como ramificações que 
permitissem ao público se locomover junto aos cabaretas dentro dessa máquina criada como uma parasita dentro da máquina cidade.

Ao se entender essa máquina cabaré como uma pós-opera, dialeticamente se cria um contraste com o considerado gênero maior ou elevado das artes e a busca wagneriana pela harmonia. O cabaré, por outro lado, é entendido como um gênero menor, e assim abre seu espaço a tudo que é baixo, se interessa especialmente por tudo que acontece da cintura para baixo do ser humano, ou abaixo da terra (underground). Enquanto a ópera busca construir uma grande fantasia com cenários e broqueis, o cabaré leva a sua espetacularidade para as ruas. O público da ópera vai com suas melhores roupas e salto alto, o do cabaré na rua sabe que caso venha a se sentar será no chão sujo e duro da urbe e que não há lugar marcado.

Na pós-ópera a orquestra não está mais presa no fosso, mas é composta pelos próprios artistas do cabaré. Tocam latas velhas e cascos de cerveja, amassam a porta de um carro, uma atriz espreme laranja, duas atrizes batem cadeiras no chão, guitarra e baixo elétrico, toda essa profusão sonora é regida por uma maestrina de muletas. O som produzido é a música precária dessa máquina cidade.

O teatro musical está presente em todas as cenas, mas buscando uma proximidade com sonoridades urbanas, canções de cabaré e ritmos que se relacionam com a cultura popular como o rape o repente. O cabaré sempre esteve comprometido com um lugar mais acessível ao abrir o seu palco para que artistas e não artistas possam trazer suas experimentações em meio ao divertimento. Um lugar social de troca e compartilhamento, sempre subvertendo a técnica artística que afasta o público da cena. Nesse sentido, a espetacularidade é forma de questionar as próprias lógicas do espetáculo social e consequentemente às diversas formas de opressão. O cabaré existe como modo de vida enquanto se pode rir de nossas próprias tragédias e se festeja para sobreviver mais um dia. A festa é pública e não se tem tantas vitórias para se comemorar.

A máquina cabaré ao deslocar a pesquisa cabareteira para espaços não convencionais, ruas e praças leva consigo a memória de todos os cabarés e artistas 
que tiveram suas histórias apagadas em detrimento de uma arte maior ou elevada. Elementos que compõem a estética cabareta são modificados por esse deslocamento e expansão das ações, mas seguem ali. Enquanto o movimento da teatralidade oficial é o de aparar arestas e mutilar excessos na busca pela coesão, o cabaré traz o excedente em praça pública.

O cabaré adquire nova mobilidade ao sair de espaços pequenos e, muitas vezes, improvisados e passar a improvisar nas ruas por onde passa. "Onde será o discurso da ditadora queer?”, diz uma atriz/iluminadora com o refletor na mão, o diretor coça a cabeça e responde que não sabe, uma outra atriz sugere que seja na frente de um grande portão na entrada do Mercado Central. É assim que características do cabaré vão ganhando novos ares e descobrindo novas frestas em que possam se instalar.

Esta característica de adaptar-se a diferentes contextos tão fortes no cabaré tem muito a ver com elementos particulares sobre a linguagem, sendo talvez a principal delas o humor próprio. Como diz a mexicana Cecilia Sotres: "Tiene que ver con lo que nos duele, nos angustia, lo que no nos gusta, lo que nos parece injusto, aquello ante lo que sentimos impotencia" (Sotres, 2016, p.73). É no riso que reside a maior potência política do cabaré, que não perdoa nada, ri do que é difícil e mais dolorido, como forma de libertação. A mesma autora também coloca como o cabaré tem o poder de falar sobre nosso próprio tempo: " el cabaré se nutre de todo tipo de temas, enfocándose en la actualidad, corresponde a su época inmediata" (Sotres, 2016, p.22). Por isso também o cabaré talvez seja tão marginalizado pela história oficial das artes cênicas, através do humor fala do agora, do imediato e do efêmero.

A figura do mestre de cerimônias ou conferencista é uma das características mais marcantes para o cabaré e evidentemente não poderia ficar de fora. Christina Streva (2017, p.104) expõe que essa figura "relaciona-se diretamente com a plateia, ignorando a ilusão, apresentando e comentando os números e chamando o espectador à participação". Nesse espetáculo o conferencista é uma persona assumida por todas as artistas ao conduzir o público por diferentes logradouros e também direcionar olhares na tentativa de alinhavar cidade e cenas. Essas mestres de cerimônias muitas vezes tem a função de apresentar e dialogar com 
a cidade que não é apenas cenário estático no fundo da cena, mas um organismo vivo e pulsante que gera o tempo todo teatralidade. É assim que esse coro de conferencistas traça um fio em meio ao labirinto cidade, que no fundo tem a função de revelar ao espectador que ele também é um mestre de cerimônias precisando fazer escolhas e suas próprias relações diante de tantos fragmentos de cenas ensaiadas e vividas.

Sendo o cabaré cabo desencapado de alta periculosidade em que podemos ver a corrente elétrica correndo livremente, muitas figuras que no teatro oficial estariam trabalhando muito longe dos olhos da plateia aqui se tornam cena. É o caso da contrarregra, que como o próprio nome já nos diz tem a função técnica de recolher e posicionar elementos em cena, mas também possui o elemento transgressor de ser contra todas as regras. Uma performance contínua e carismática que dialoga com o próprio funcionamento dessa máquina. Oferece alternativa de olhar e performatividade singela frente a grandiloquência dos textos e presenças espalhafatosas, é como um cupim roendo a madeira ou a ferrugem que revela que em meio a tanta espetacularidade existe vida pulsante. A contrarregra entre suas funções técnicas encontra espaços para transgredir e debochar do autoritarismo das cidades e das próprias artistas, atua eficientemente na revelação de uma das características mais importantes do cabaré: a dispersão como combate a todo o autoritarismo seja esse político ou estético.

\section{Fenda 5: Contrarregra}

E nas fendas, outra pequena fenda. A fendinha das fendas. A erva daninha contrarregra, que se mistura e se afasta, e tenta corroer, como minúsculo organismo que é, as arquiteturas formadas efemeramente. Vagueia pela multidão. Depois se entedia. Vagueia novamente.

A contrarregra foi colocada em cena, inicialmente, para cumprir a função costumeira de auxiliar nas trocas de roupas e guardar os objetos. Tratando-se de um cabaré, permitia-se acomodá-la como parte da estrutura do evento, integrada, e à vista a finalidade de sua presença.

Escolheu seu figurino: um vestido longuete rosa e preto, do tipo sereia, com 
ombreiras. Botou seu coturno vermelho de cano alto, óculos espelhados, maquiou-se. Arrumaram-lhe um carrinho de carga, com caixas, para que pudesse se deslocar, seguindo o fluxo percorrido pelas artistas, e por entre o público.

Não eram muitas as suas tarefas. Um tempo longo sem nada a fazer. Encontrou as primeiras distrações: dar voltas pela praça, entender as distâncias, os pontos fixados para as trocas. O carrinho barulhento sobre o chão de paralelepípedos. Pareceu-lhe bom seu micro mundo. Ouvir música no mp4 antigo, também pareceu bom. E fumar. E comer. Antes comer, depois fumar. Reuniu ao vestido uma marmita rosa com alças pretas, de design moderno. O tempo longo. Todo mundo com fome. Dividiu os lanches, já cortados em pequenas fatias, dentro da marmita. O Sudoku e a caneta, na bolsinha. Tinha também giz para riscar, em algum lugar, o jogo da velha.

Deu-se conta de poder ser inútil, de não participar da trama, muitas vezes passar despercebida. Um corpo-carrinho disfuncional. Uma pequena máquina inútil dentro da grande máquina. Ela mesma nunca foi Hamlet. Não pesou sobre si “ser ou não ser”. Não era. Era corpo-carrinho-máquina, sem dor. Ela, sim, cada vez mais non sense. Ajeitava as caixas e se deitava, para que o tempo passasse. Sem ser a que o rio não conservou. Isto nunca. Por vezes, aproximava-se de alguém atento/a ao espetáculo só para falar mal do ritmo, da interpretação, ou do que the viesse. Quem pode danificar a erva daninha senão outra erva daninha? Bem pequenininha, é verdade. Uma pequena Dadá. Dadaistinha.

Respeitável público, respeitável leitora e leitor, olhemos melhor para a nossa dadaistinha, antes que os grandes embaixadores do sentimento apareçam. É Giulio Carlo Argan quem diz:

Visto que existe um conceito de arte, existem objetos artísticos e existem técnicas artísticas, é preciso contestá-los a todos: a verdadeira arte será antiarte. Um movimento artístico que negue a arte é um contrassenso, e Dada é este contrassenso. Negando o sistema de valores por inteiro, nega-se a si mesmo como valor e também como função, sendo a função uma ação dotada de finalidade e valor. Reduz-se assim a uma pura ação, imotivada e gratuita, mas justamente por isso desmistificadora em relação aos valores constituídos. (Argan, 1992, p.356).

Que adorável essa passagem! E aplicável merecidamente à nossa pequena 
erva cultivada no solo do Cabaret Voltaire e que veio aqui desabrochar. Ela é um contrassenso. Ser e não ser, em igual medida. Fez cartões de visita com a intenção de entregá-los para pessoas renomadas da classe teatral, caso as encontrasse na mini multidão. Encontrou. E apenas avisou: se gostar do meu trabalho, estou à disposição. Pegou o cartão errado. Pegou o cartão do sindicato das anarquistas, onde se lia: Contra todas as regras e a favor do caos: fale comigo. Que distraída! Meio insensata e distraída. E que abusada.

A nossa ervinha quer nos afrontar. Disse-nos, de início, ser apenas uma trabalhadora, pouco afeita aos vícios da intelectualidade. Levantou as mãos e nos jurou jamais ter lido o grande livro de Karl Marx, mas insinuou haver, no curto espaço da apresentação (longa para ela), certa luta de classes. Imaginem! Chegou mesmo a falar em hierarquias postas entre nós. Não quisemos estender a discussão. Ela era perigosinha. Depois, descaradamente, assumiu ter lido, sim, outras teorias. Nos jogou na cara que estávamos num impasse, e pôs-se a dar um texto, tal qual uma máquina de dar texto: A divisão do trabalho artístico em produção material e produção ideal, ao menos na teoria, é promovida pela corte através da arte; ela é, no âmbito feudal, um reflexo das relações de produções modificadas. E seguiu explicando que nós artistas, na hora da divisão, escolhemos um lado, e não foi o lado dos trabalhadores e das trabalhadoras. Ficamos pasmas diante da acusação de pertencermos à elite. Ela que ficava deitada, ali de qualquer jeito, enquanto suávamos para nos colocar como máquinas desejantes! Descobrimos, mais tarde, o plágio. O texto que havia cuspido em nós, e que aqui deixamos em itálico, estava na página 84 do livro de Peter Bürger, numa edição de 2008, da Cosac Naify, e era um excerto de M. Müller. Não adiantou the falarmos sobre o plágio. Ficou parada, pensou um pouco. Parecia ter um herbicida nas mãos, e disparou contra nós: que não tínhamos nenhuma moral no quesito apropriação, que nos apropriávamos de tudo, de técnicas, de produção intelectual, e seja lá do que for que aparecesse pela frente. Que éramos ervas rasteiras, que nos espalhávamos. E uma porção de outras coisas que é melhor não lembrar. Isto vindo dela que, soubemos depois, dizia para o público que ia tirar um cochilo porque não era refém do trabalho, e que comia, bebia e dormia quando tinha fome, sede e sono. Que era autônoma. E que a arte nunca foi autônoma. Sim, 
ficamos sabendo disto, senhoras e senhores.

No final das apresentações, a nossa insensata erva daninha, antiartista, se punha entre nós e se inclinava perante o público para receber os aplausos. Que contrassenso. A arte não é séria, repetia a nossa contrarregra que gostava mesmo era de dar espetáculo.

\title{
Outras fendas: Desdobramentos vegetais
}

\author{
Devo falar de mim Eu quem \\ De quem se fala, quando \\ se fala de mim (Mueller, 1993, p.20).
}

Uma máquina não é apenas técnica, é parte de uma máquina social que usa homens como peças de sua engrenagem [...] o mecânico é parte da máquina mesmo quando deixa de exercer a sua profissão [...] a máquina da justiça inclui escritórios, livros, símbolos, mas também mulheres, acusados, fluxos, eróticos [...] Não existe máquina puramente técnica, toda máquina já é parte de uma máquina mais ampla, de uma máquinica e de uma maquinação na qual entram os desejos e as conexões (Pelbart, 2011, p.8).

"Eu era Hamlet”11, "aquela que o rio não conservou”'2, ou um diretor anarquista. Agora olho para a máquina-utopia criada. Posso ver as suas imperfeições e essas se tornam a melhor coisa a se oferecer. São as vicissitudes e consequências das escolhas. Delas já não podemos escapar: a construção de um cabaré em processo e colaborativo com mais de 17 artistas envolvidos, cachês divididos igualmente, todas as funções executadas por esses próprios artistas e ir às ruas em busca de uma heroína.

Uma máquina em funcionamento é sempre uma máquina sendo construída. Eu pensei que dessa vez tudo seria diferente, que minhas expectativas não seriam asfixiantes para os demais e que pela primeira vez nos escutaríamos. Essa máquina seria uma utopia colaborativa e que simplesmente funcionaria. Mas tal máquina é feita de muito desejo, tentativa, esperança e falha. Ela é feita pelo acaso e pelo jogo do instante. Máquina para ressuscitar mortos, para nos fazer marchar mesmo sem saber para onde vamos. Isso é um processo: caminhada no escuro

\footnotetext{
${ }^{11}$ Citação do texto de Heiner Müller (1987, p.25).

12 Citação do texto de Heiner Müller (1987, p.27).
} 
desdobramento vegetal. Ramificação.

Eu lutei por não estar nessa máquina e quando percebi estava em seu interior, em seu coração, eu era parte dela. Um destino que tento fugir. Essa máquina selvática traçada na palma da minha mão é o que o mundo me deu: é uma família anti-família e esperança. Contradições. A máquina tem peças que se organizam e reorganizam combinando distintas engrenagens. Nada disso foi sobre ser ou fazer a melhor máquina cabaré. Mas sim a máquina que somos. Confusa, dissonante, apaixonada, intransigente e amorosa. Nossas máquinas frustrações e expectativas.

Máquina organismo carregada de ideologias ultrapassadas e grandes esperanças (heranças modernas). Máquina mística e alquímica ao combinar e realinhar cidade, arquitetura, impulso e situações. Feita de restos de comida e regurgitadas pelos dentes engrenagens motores. Máquina Antropófaga. Em consonância com Pelbart (2011, p.5):

um efeito que só é compreensível a partir dessa molecularidade em que são meio que variadas as personagens e situações em uma polivocidade extrema em que elementos sonoros, visuais, gestuais não necessariamente confluem, produzindo algo como um sistema de intensidades particular que explode polifonicamente a narratividade que parecia acolhê-los e os estrangulamentos que pareciam encerrados.

Nesse processo para construir essa máquina erva daninha cabaré o coletivo desenvolveu seis máquinas coletivas - esboços. Protótipos do que poderia ser e conter a nossa máquina. Utilizou as palavras de Heiner Müller e suas próprias. Fez sets cinematográficos, exercícios autorreflexivos, cenas de cabaré, derivas e simplesmente esteve na cidade ocupando e sendo ocupadas. Invadindo e sendo invadidas. Comendo e sendo comidas por olhares e mosquitos. Ecoando e reprocessualizando questões mobilizadas pelo processo de criação mais desafiador que muitas de nós passaram: um trabalho de cabaré para o espaço público.

Hoje, não sei quantos anos depois, em meio a uma pandemia que impede o exercício coletivo presencial reverberam ainda com mais força algumas questões que acompanharam toda a criação, lançadas por Francisco Mallmann: "Como falar ferida? Como falar de dentro de um cabaré? Como duvidar da minha própria 
palavra?".

A máquina cabaré radicante já não se encontra na mesma praça.

O cavalo de Tróia sumiu.

Mas alguma coisa foi desprogramada para sempre.

Cabaret Macchina foi uma criação de Amabilis de Jesus, Amira Massabki, Bruna Costa, Cacá Bordini, Cali Ossani, Cibelle Gaidus, Francisco Mallmann, Gabriel Machado, Halyne Czmola, Jo Mistinguett, Leonarda Glück, Leo Bardo, Matheus Henrique, Nina Ribas, Patricia Cipriano, Patricia Saravy, Ricardo Nolasco, Semy Monastier, Simone Magalhães, Stéfano Belo, Vi Gabarda e Thalita Sejanes.

\section{Referências}

AKSELI, Virtanen. O discreto charme do precariado, posfácio a Máquina Kafka. In: GUATTARI, Félix. Seleção e notas de Stéphane Nadaud. Trad. e prefácio de Peter Pál Pelbart. São Paulo: n-1 edições, 2011.

ARGAN, Giulio Carlo. Arte Moderna. Trad. Denise Bottmann e Federico Carotti. São Paulo: Companhia das Letras, 1992.

BENJAMIN, Walter. Teses sobre o conceito da história. In: Walter Benjamin- obras escolhidas. Vol. 1. Magia e técnica, arte e política. Ensaios sobre literatura e história da cultura. Trad. Sérgio Paulo Rouanet. São Paulo: Brasiliense, 1987.

BEY, Hakim. TAZ - Zona Autônoma Temporária. Trad. Alexandre Barbosa de Souza. São Paulo: Veneta, 2018.

BOURRIAUD, Nicolas. Radicante. Trad. Michèlle Guillemont. Buenos Aires: Adriana Hidalgo, 2009.

BÜRGER, Peter. Teoria da Vanguarda. Trad. José Pedro Antunes. São Paulo: Cosac Naify, 2008.

COHEN, Renato. Work in Progress na Cena Contemporânea. São Paulo: Perspectiva, 2004.

DEBORD, Guy. La société du spectacle (A sociedade do espetáculo). Documentário legendado em português. Paris: Simar Films, 1973. Disponível em:

https://www.youtube.com/watch?v=A4FAJsFqHeO Acesso em: 01 jun. 2021.

EAGleton, Terry. As Ilusões do Pós Modernismo. Trad. Elisabeth Barbosa. Rio de 
Janeiro: Jorge Zahar, 1998.

ECO, Umberto. Obra Aberta: forma e indeterminação nas poéticas contemporâneas. São Paulo: Perspectiva, 2005.

FARACO, Carlos Alberto. Linguagem e Diálogo - as idéias línguisticas do círculo de Bakhtin. Curitiba: Criar Edições, 2003.

FORTIN, Sylvie. Contribuições possíveis da etnografia e da auto-etnografia para a pesquisa na prática artística. Revista Cena, Porto Alegre, n. 7, p. 77-88, 2006.

GUATARRI, Felix. Máquina Kafka. Seleção e notas: Stéphane Nadaud. São Paulo: n1 edições, 2011.

HARAWAY, Donna. Manifesto ciborgue: Ciência, tecnologia e feminismo-socialista no final do século XX. In: TADEU, Tomaz. Antropologia do ciborgue: as vertigens do pós-humano. 2 e.d. - Belo Horizonte: Autêntica Editora, 2009.

LEPECKI, A. Coreo-política e coreo-polícia. Ilha Revista de Antropologia, Florianópolis, v. 13, n. 1,2, p. 041-060, jan. 2013. Disponível em: https://periodicos.ufsc.br/index.php/ilha/article/view/2175-8034.2011v13n12p41/23932 Acesso em: 14 mai. 2021.

MARGULIS, Lynn. Planeta simbiólico: uma nova perspectiva da evolução. Trad. Laura Neves. Rio de Janeiro: Rocco, 2001.

MARCONDES, Renan. Breve Apontamento sobre Hamlet-Ofélia em 'HamletMáquina'. Revista Performatus, Inhumas, ano 2, n. 12, out. 2014. ISSN: 2316-8102. Disponível em: https://performatus.com.br/estudos/hamlet-ofelia-heiner-muller/ Acesso em: 01 jun. 2021.

MARX, Karl. O 18 de brumário de Luís Bonaparte. Trad. e notas Nélio Schneider ; prólogo Herbert Marcuse. São Paulo: Boitempo, 2011.

MÜLLER, Heiner. Quatro textos para teatro. Mauser; Hamlet-máquina; A missäo; Quarteto. Trad. F. Peixoto. São Paulo: Hucitec, 1987.

MÜLLER, Heiner. Medeamaterial e outros textos. Trad. M. Renaux. Rio de Janeiro: Paz \& Terra, 1993.

PRECIADO, Paul B. Multidões queer: notas para uma política dos "anormais". Trad. Cleiton Zóia Münchow e Viviane Teixeira Silveira. In: Estudos Feministas, Florianópolis, 19(1): 312, janeiro-abril/2011.

ROCHA, Lucía Naser. De la politización de la danza a la dancificación de la política. In: Trans-in-corporados: Costruindo redes para a internacionalização da pesquisa em dança, 2017, Rio de Janeiro. Anais eletrônicos. Campinas, Galoá, 2017. Disponível em: <https://proceedings.science/trans-in-corporados2017/papers/de-la-politizacion-de-la-danza-a-la-dancificacion-de-la-politica- 
?lang=pt-br> Acesso em: 10/05/2021.

RUSSO, Mary. O grotesco feminino: risco, excesso e modernidade. Trad. Talita M. Rodrigues. Rio de Janeiro: Rocco, 2000.

SEJANES, Thalita Alves. Trajeto-processos de uma criação selvática pela cidade. Dissertação (Mestrado em educação em ciências e em matemática). Universidade Federal do Paraná, Curitiba, 2020.

STREVA, Christina. Por um ator-provocador e um professor-criador: uma pesquisaação sobre a performance de cabaré. Tese (Doutorado em Artes Cênicas) Universidade Federal do Estado do Rio de Janeiro, Rio de Janeiro, 2017. Disponível em: https://cabareincoerente.com/referencias/bibliografia/

SONTAG, Susan. Sob o signo de saturno. Trad. Ana Maria Capovilla e Albino Poly Jr. São Paulo: L\&PM, 1986.

SOTRES, Cecilia. Introducción al cabaret (con albur). Paso de gato. Cidade do México: Realizada em coedição com Ediciones Chulas, 2016.

SUDARE, Lívia. Die Höchste Eisenbahn: Um aviso do cabaré alemão diante da ameaça nazista. Sala Preta, São Paulo, vol. 19, n. 2, p. 48-63, 2019.

TRÓI, Marcelo de. Cidade, ferida aberta: uma etnografia urbana com o coletivo Selvática. In: Artivismos das dissidências sexuais e de gênero / Leandro Colling, organizador. Salvador: EDUFBA, 2019.

Recebido em: 11/06/2021

Aprovado em: 12/08/2021 